\title{
INFORMAL ENGLISH LEARNING WITH ONLINE DIGITAL TOOLS: NON-LINGUIST STUDENTS
}

\author{
Oksana Yurieva, Tetiana Musiichuk, Dina Baisan
}

\author{
The National University of Ostroh Academy, Ostroh, Ukraine \\ oksana.iurieva@oa.edu.ua
}

\begin{abstract}
The internet has offered numerous opportunities for educational content delivery. The main current delivery models for learning a language online range from more formal structured approaches provided by schools and universities, which typically take place in a VLE (Virtual Learning Environment) or LMS (Learning Management System), to more informal unstructured approaches, including Virtual Worlds like Second Life and MMORPGs (Massively Multiplayer Online Role-Playing Games) like World of Warcraft.

The purpose of this study is to analyse the experiences and perceptions of the online digital tools that provide engagement with the English language outside the classroom by the non-linguist students at a Ukrainian public university. The study is based on the quantitative and qualitative data collected employing an online questionnaire including Likert-type ratings, multiple-choice questions, and free-text responses to open questions. The questionnaire inquires about students' experiences with 17 technologies not related to their classroom activities, how frequently they are used, how helpful the students find them for their language acquisition in general, and how useful they are considered for the development of particular language competencies (writing, reading, speaking, listening, pronunciation, grammar, communicative competence). The results of the survey attest to regular students' engagement with the English language involving online technologies, which leads to implications for foreign language learners, teachers, and researchers of second language acquisition for incorporating online digital tools for foreign language acquisition beyond the classroom. Being aware of how students engage with technology outside the classroom may facilitate educators in increasing learners' engagement with the foreign language, provide additional practice, and produce an emotional response, which increases retention of information.
\end{abstract}

Keywords: informal English; language learning; second language acquisition; digital technology; online learning; EFL students

\section{Introduction}

Most human learning occurs in an informal context (Eraut, 2000) from infancy until the end of life and is unplanned, unintended, and often unconscious, resulting in tacit or implicit knowledge, understandings, skills, and attitudes (Rogers, 2008). Today's adolescents' continuous engagement with technology has drastically changed the way young students learn (Prensky, 2001; Godwin-Jones, 2018). Such shifting conditions of learning and teaching have turned EFL educators' attention to computer-assisted language learning. The main current delivery models for learning a language online range from more formal structured approaches offered by schools and universities, which typically take place in a VLE (Virtual Learning Environment) or LMS (Learning Management System), to more informal unstructured approaches, including Virtual Worlds like Second Life and MMORPGs (Massively Multiplayer Online Role-Playing Games) like World of Warcraft (Hockly, 2015). Moreover, high-speed internet access and the availability of online tools have made it possible for non-native speakers to be increasingly exposed to the authentic English language. Toffoli and Sockett (2013), for example, claim that English-learning students in France spend more time learning English informally than they do in the classroom which leads to considerable individual differences in initial knowledge of the target language and unexpected changes in language skills and repertoires (p. 7). Supported by the theory of incidental language learning (Schmidt, 1994), learner autonomy (Holec, 1981) and informal language learning (Benson, 2011), online informal learning of English can be viewed as selfdirected, independent from formal context learning utilizing various digital devices and online resources (Lee \& Dressman, 2017).

\section{Literature review}

The origin of informal learning can be traced back to John Dewey, who, although not speaking about the concept itself directly, refers to the learning from experience and the role of reflection in his 1938 book Experience and Education (Messmann, Segers, \& Dochy, 2018). The term "informal learning" was first introduced by Knowles in 1950 in his work Informal Adult Education (Conlon, 2004). When it comes to conceptualizing informal learning, Marsick and Watkins can be considered pioneers whose definition of

(C) Oksana Yurieva, Tetiana Musiichuk, Dina Baisan. 2021. Published by Igor Sikorsky Kyiv Polytechnic Institute. This is an Open Access article distributed under the terms of the licence CC BY 4.0 
informal learning is frequently referred to in the existing literature (Messmann et al., 2018=). In their view, informal learning results from experience, takes place outside formal educational settings in a planned or unplanned manner, happens mostly unconsciously, and the activities are not specifically aimed at learning (Watkins \& Marsik, 1992).

Although informal learning has been discussed for several decades, it has not received significant attention compared to studies of formal learning. For instance, Benson \& Reinders (2011) claims that there is no solid reason for presuming that out-of-class learning is any less effective than classroom learning, and therefore assumes that we could reasonably expect researchers to pay equal attention to both. However, he admits that this is not the case since, in contrast to the many thousands of published studies on classroom language learning in the recent literature, there are very few studies of language learning beyond the classroom (p. 8). Trinder (2017) argues that despite the sizeable literature on the classroom-based use of specific digital resources, there is a need to pay more attention to online informal learning of English as, according to the researcher's view, few studies have investigated how students evaluate increased exposure to English in terms of learning potential (Trinder, 2017). However, due to the recent discourse of lifelong learning, the fact that learning can occur outside formal educational institutions has gained wider recognition (Rogers, 2008), especially now when online tools increase the choices and opportunities for language learners to create an authentic learning environment.

Although this area of research is still in its infancy, the current literature attests to different findings of the outcomes of informal learning with digital tools. For example, Burston $(2014,2015)$ and Sung, Chang, and Yang (2015) have concluded that mobile language learning in informal settings generates moderate results. Other studies have suggested more positive outcomes for language learners in such domains as pronunciation (Mitra et al., 2003), vocabulary (Jensen, 2017; Sundqvist \& Wikstrom, 2015), reading and listening (Sylven \& Sundqvist, 2012) and formal testing (Lai, Zhu, \& Gong, 2020; Sundqvist \& Wikstrom, 2015). Hall (2009) argues that informal learning comprises essential conditions for human development and is crucial for effective learning. In his thematic study of learners' and educators' voices, he highlights that "online tools can be used proactively by educators, using specific tasks to enable learners to fuse their informal and formal learning spaces, and thereby enhance their decision-making confidence" (Hall, 2009, p. 29). Hall (2009) contends that within educational contexts, these tools can provide learners with more opportunities to extend their formal learning into more informal spaces by fusing online tools into a taskoriented personal learning environment (p. 29).

Trinder (2017) regards informal learning as learner-controlled, not linked to any course or institution, taking place outside the classroom, and quotes Stevens (2010), who argues that this is a kind of "learning resulting from daily life activities related to work, family or leisure. It is not structured (in terms of learning objectives, learning time or learning support) and does not lead to certification" (p. 12). Even though some (Tissot, 2004; Stevens, 2010) claim that informal learning in most cases is non-intentional (or incidental/random), Trinder (2017) believes that learners are aware of the process and the product of learning (p. 2).

The findings of Trinder's (2017) empirical study based on surveying 175 Austrian university students' practices and preferences related to new media in independent informal online-learning settings suggest that television series/films are the most highly ranked resource in terms of both, frequency of use and skills acquisition whereas the use of communication media (in particular, Facebook and chat) is not regarded as highly useful and contributing resource to skills acquisition. Surprisingly, online grammars and language learning sites show low ranking in terms of their regularity of use and perceived usefulness (Trinder, 2017).

Sockett, in his 2013 emic study, contends that the data regarding vocabulary gains as well as fluency and comprehension improvements are evident, admitting that the mechanisms at work in such language development are difficult to study due to the private nature of informal learning (Sockett, 2013, p.48). He suggests that online informal learners are mainly aware of their language gains as they perceive, encode, and re-use chunks of idiomatic language (p. 50).

As for the teachers' perceptions of online informal learning of English, educators seem to be aware of the potential opportunities for language acquisition that it can offer, but they feel the need for adaptations of educational frameworks which take such resources into account. Toffoli and Sockett (Toffoli \& Sockett, 2015) conducted a survey which allowed them to analyse teachers' awareness of the online informal learning of English and its effects on their students' language skills and concluded that teachers estimate the number of students involved in some regular online activity in English to be much lower than indicated by students. According to the research, teachers demonstrate a rather ambivalent attitude towards online informal learning of English: evaluating its effects on students' English skills as positive, they have some reservations regarding the rigidity of teaching programmes, illegal use of online resources, and even intrusion into students' private lives. While conducting their research, Toffoli and Sockett (2015) observed that according 
to quantitative studies, many learners spend more time learning English informally than they do in the classroom (p. 7).

To understand students' perceptions of technology, their preferences and beliefs about the usefulness of a particular online tool for their language learning, and to analyse the evolution in language students' attitudes towards the use of new technologies in the period between 2006 and 2011, Steel and Levy (2013) surveyed undergraduate foreign language students enrolled at The University of Queensland and compared their findings with two other studies, conducted in 2006 by Conole (2008) and Peters, Weinberg, and Sarma (2009). Thus, in her 2008 paper, Conole (2008) argues that many can see how fundamentally different students were in comparison to previous generations in the way they process information and learn. She mentions terms such as "digital natives", "the net generation", "the Nintendo generation", "the neomillenial generation" used by other scholars to describe this shift (See, for example, Oblinger \& Oblinger, 2005; Prensky, 2001; Baird \& Fisher, 2005). She characterises this new generation as being comfortable with technologies and adept at working in multi-modal environments, tending to more strategic, task-oriented, and experiential learning, more comfortable in a group setting than previous generations, and therefore using multiple communication channels to access information and communicate (Conole, 2008, p. 131). According to Peters et al. (2009), there can be observed four trends in students' attitudes towards and perceptions of online activities: students find computer-assisted activities useful; prefer less-mediated more authentic activities; consider to be more useful the computer-assisted activities done individually rather than collaborative ones, and; regard traditional types of computer-assisted activities (listening, grammar, vocabulary drilling) more useful than blogs or WebQuests (p. 869).

Having compared the two above-mentioned studies and their own findings in 2011, Steel and Levy (2013) concluded that many technologies underpinning such activities as "typing your homework", "reading texts on the computer", "searching the web for information", "listening to media broadcasts on the web", "doing a PowerPoint presentation" as well as text messaging and emailing have become normalised according to Bax's criteria (Steel \& Levy, 2013, p. 307). They also noticed the transformation and enhancement of some technologies like language dictionaries, verb conjugators, and even electronic translators, which continue to be well-perceived and widely used by students across the five-year span (p. 315). However, the researchers observed the tendency of some of the technologies to experience a decrease in popularity with the student population, namely wikis, blogs and, virtual worlds, which were not widely employed (p. 318). Steel and Levy (2013) noticed another important trend that is growing exponentially until today, arguing that mobile phones that turned into smartphones and even microcomputers in their own right became ubiquitous and offer new possibilities for language learning (p. 317).

More recent studies, indeed, have found that smartphones have become one of the most popular media for informal language learning (Sad et al., 2020; Putrawan \& Riad, 2020; Huzairin, Putrawan, \& Riadi, 2020; Li et al., 2020; Peng, Jager, \& Lowie, 2021; Jurkovič, 2018). As for out-of-class language learning digital tools, researchers have looked into social networking sites (Ismail \& Shafie, 2019; Che \& Ibrahim 2018), scrutinizing Instagram (Gonulal, 2019) or Facebook (Purnamasari, 2019), mobile instant messaging (Pooley, Midgley, \& Farley, 2019), WhatsApp interaction (Akkara et al., 2020), subscription video streaming services (Dizon, 2021), multi-player gaming (Scholz \& Schulze, 2017; Vazquez-Calvo, 2020), e-courses (Solotovets, Chigisheva, \& Dubover, 2019).

The results of a quantitative study on the use of smartphones for informal language learning in two Turkish universities have shown that students use their smartphones mostly to engage in extensive listening and speaking activities rather informally through watching English videos, TV series, movies, news, etc., with subtitles or speaking to foreigners in English on social media (Sad et al., 2020, p. 16). The researchers also report that the participants of their study occasionally use their smartphones to improve their English skills in general via apps or websites formally designed for language learning purposes (Sad et al., 2020, p. 17). With regard to reading and writing skills, participants were found to hardly use their smartphones to engage in rather informal reading and writing activities such as reading English e-books, blogging in English, commenting on English websites, reading on international forums, or reading English news and articles (Sad et al., 2020, p. 17).

The researchers also studied students' attitudes towards "the hostile role of smartphones" and concluded that the participants regard smartphones as tools scarcely having adverse effects on learning English in general except for one reservation that they "forget English language contents quickly" because they "can access them easily" (Sad et al., 2020, p.18).

Studies in the Indonesian context (Putrawan \& Riadi, 2020) indicate that English is not the predominant language used by undergraduate learners, and even though smartphones offer endless opportunities to engage with authentic language, "their smartphones are not utilised for online activities of EFL informal learning to 
a maximum extent" (p. 698). The research found that most of the participants use English for online activities such as "using language learning applications, accessing online dictionaries, writing down new words in a foreign language, playing games with reading instructions, accessing websites with language learning exercises, playing language games, and listening to English music" (Putrawan \& Riadi, 2020, p. 698). The findings of another study (Huzairin, 2020, p. 103) reveal that the participants more frequently access content and information from their smartphones for receptive rather than interactive/productive online activities. Their mother tongue is still predominantly used for their online activities. The mean score of the perceived EFL proficiency of those who frequently perform online activities in English is statistically and significantly higher than those performing online activities in their native language, although the difference is not statistically significant (Huzairin et al., 2020, p. 103).

According to the study findings in the Korean context (Lee, 2020, p. 155), informal digital learning of English correlates with the perception of English as an international language since informal digital learning enabled them to experience diverse accents and users of English. The study has also found that the students who tended to practice activities for informal digital learning of English more frequently had higher TOEIC scores. Regarding the use of certain applications, a study on informal learning through WhatsApp, in which the participants were given collaborative learning activities and problem-solving tasks at regular intervals for over two semesters, indicated a statistically significant difference in their speaking skills and considerable change in their perceptions based on the band descriptors of IELTS (Akkara, Anumula, \& Mallampalli, 2020, p. 250).

Understanding learner autonomy and affective variables such as anxiety, grit, self-confidence, and motivation is crucial for gaining an insight into the learners' attitudes towards informal digital language learning. The studies have found that diverse informal digital language practice engaging both form- and meaning-focused foreign language learning activities plays an important role in enhancing students' affective variables as well as willingness to communicate in the target language (Lee, \& Drajati, 2019, p. 168). Examining language learners' self-initiated engagement with mobile learning activities in China, researchers (Peng, Jager, \& Lowie, 2021) applied a holistic person-centred approach and singled out six types of learners, each possessing a distinct package of motivational, emotional, and linguistic interaction, ranging from those who barely spent time on English learning outside the classroom to those who allocate a comparably large amount of time to practising both receptive and productive skills (Peng et al., 2021, p. 16).

In recent decades, researchers have recognised the fact that autonomy in language learning entails the use of innate cognitive functions and language as a social tool, therefore moving away from understanding autonomy as self-paced individualised learning to viewing it in a social context (Godwin-Jones, 2019, p. 8). Out-of-class language learning is now viewed as one affected by many factors, including the learner's linguistic and educational background, the availability and suitability of chosen or found online resources, the learner's motivation, knowledge, and ability to use and re-use the resources productively, and the degree to which the experience fits the learner's self-concept in the present and for the future (Godwin-Jones, 2019, p. 8).

This literature review situates informal learning of English with online digital tools within the constructivist framework, drawing attention to learner autonomy and self-awareness. In this study, one of our fundamental contentions is that the benefits of informal digital language learning do not remain unnoticed by language learners. Even though the decision to engage in informal learning is not initially driven by the intention to improve one's English skills, it is nonetheless a conscious choice to engage with foreign language resources even when the content is available in their native language. We believe that it is also a side reason often claimed by informal language learners, which suggests that intrinsic motivation is one of the driving factors. This study is an attempt to shed light on the choice of particular online digital tools by the language learners and on the reasons behind this choice while creating a personal learning environment; it is to fill the gap in the research into the attitudes towards the non-structured learner-controlled language learning by non-linguist students in Ukrainian context within the shifting global reality.

\section{Method}

\subsection{Research aim}

The purpose of this study is to analyse the experiences with and the perceptions of the online digital tools that provide engagement with the English language outside the classroom by the non-linguist students at a Ukrainian public university. As discussed above, there is a need to pay more attention to the informal learning of the English language with new technologies since this may contribute to a better understanding of the benefits of such increased exposure to English in terms of learning potential. Therefore, we are going to focus on the following areas of student behaviour and attitudes: 
1) frequency of use of the technologies that provide engagement with the English language;

2) perceptions of usefulness of the technologies for the language acquisition by the students;

3 ) reasons behind the choice of a particular digital tool.

\subsection{Research design and data analysis tools}

Data were collected quantitatively and qualitatively through a questionnaire created in google forms and aimed to elicit students' demographic information, their engagement with digital technology that involved the English language, the frequency of use of certain technologies and their perceived usefulness for the language acquisition, and the reasons behind choosing (or neglecting) a certain online tool. The questionnaire was designed in the participants' native language (Ukrainian), included Likert-type ratings, multiple-choice questions, and free-text responses to open questions, and was sent to their corporate university emails. The participants were offered a list of 17 tools and asked to answer the following questions to gather data about the frequency of use of a particular digital tool: "How often do you use (name of technology) in the English language outside the classroom?"; its perceived usefulness: "How beneficial do you find this tool for your language improvement?"; which areas of language it helps to improve: "If you use this tool, which language skills do you think it helps you develop?". The Likert-type scale was used requesting them to evaluate how frequently the technologies are used $(1-$ never; 2 - rarely; 3 - quite frequently; 4 - almost always or always) and how useful they find the technologies in general (1 - not useful at all; 2 - rather not useful; 3 - difficult to say; 4 - rather useful; 5 - extremely useful). The students were also asked to choose which skills are best developed through each technology (writing, reading, speaking, listening, pronunciation, grammar, grammar, communicative competence).

In order to elicit the quality of students' informal digital language learning activities and gain in-depth insight into the findings of the questionnaire, the participants were asked open-ended questions.

A pilot survey of 15 students was conducted to make sure all information provided to the participants was clear and reasonable in length. Prior to administering the survey, the author informed participants that the activities in the questionnaire referred to self-directed English learning with digital devices and Internet resources which were not directly linked to formal language learning to exclude extracurricular activities and instructor-assigned homework.

To answer research questions 1 and 2, data were analysed using IBM SPSS Statistics 25 as well as Google forms analysis tool. For research question 2, the relevant qualitative data were sorted, coded, and synthesised while filtering out irrelevant data.

\subsection{Participants and context}

The participants were undergraduate and master's degree non-linguist students $(n=132)$ at the Faculty of Economics (42.4\%), the Faculty of Political Studies and Information Management (28.8\%), Ioanykii Malynovskyi Institute of Law (19.7\%), and the Faculty of Humanities (9\%) in the National University of Ostroh Academy learning English at varying levels of language proficiency (ranging from A2 to $\mathrm{C} 1$ on the Common European Framework of Reference for Languages scale). They were all volunteers from several classes taught by different English instructors at the same university. The respondents believe that the quantity of class hours that are allotted by the university is not enough to master the English language to the desired level. Another characteristic of the sample is that after two years of general English, they focus on learning English for specific purposes, which provides very little opportunity to practice general English and therefore engenders the need for out-of-class language learning. The questionnaire in Google forms was sent to the students of the above-mentioned university on their corporate emails, and we received 132 responses from $69.7 \%$ female and $30.3 \%$ male students. While this number is small to generalise the results to all language students, in this study, we present trends and tendencies that were observed among the students of one university and which can indicate how young adults, in our case students with pre-intermediate to advanced levels of English use new technologies to practice informal learning.

Since the students are non-native speakers of English that live in a predominantly monolingual environment and consciously choose media and resources in a foreign language, we assume that the respondents are aware of their language gains while using the online technologies in the English language not exclusively for study purposes and the benefits of their informal engagement with online Englishlanguage media and resources do not go unnoticed. 
Table 1. Demographic features of the participants

\begin{tabular}{|c|c|c|c|}
\hline \multirow[t]{2}{*}{ Category } & \multirow[t]{2}{*}{ Description } & \multicolumn{2}{|c|}{ Total $(\mathrm{N}=132)$} \\
\hline & & $\%$ & $\mathrm{~N}$ \\
\hline \multirow[t]{2}{*}{ Gender } & male & $30.3 \%$ & 40 \\
\hline & female & $69.7 \%$ & 92 \\
\hline \multirow[t]{4}{*}{ Major } & Economics & $42.4 \%$ & 56 \\
\hline & Political Studies and Information Management & $28.8 \%$ & 38 \\
\hline & Law & $19.7 \%$ & 26 \\
\hline & Humanities & $9 \%$ & 12 \\
\hline \multirow[t]{5}{*}{ Grade } & first year of study & $22.7 \%$ & 30 \\
\hline & second year of study & $21.2 \%$ & 28 \\
\hline & third year of study & $43.2 \%$ & 57 \\
\hline & fourth year of study & $7.6 \%$ & 10 \\
\hline & master's degree students & $5.3 \%$ & 7 \\
\hline \multirow[t]{4}{*}{ English level } & A2 & $3.8 \%$ & 5 \\
\hline & B1 & $24.2 \%$ & 32 \\
\hline & B2 & $34.8 \%$ & 46 \\
\hline & $\mathrm{C} 1$ & $37.1 \%$ & 49 \\
\hline
\end{tabular}

Ukraine as the context in which the respondents learn English is becoming particularly favourable regarding the availability and cost of digital resources. According to the State Statistics Service of Ukraine, there are slightly over 26 million internet subscribers (with Ukraine's population being 42 million), 20 million of whom use wireless broadband access (State Statistics Service of Ukraine, 2019). The survey conducted by the Digital Transformation Ministry of Ukraine in 2019 shows that $86.5 \%$ of Ukrainians use the internet at home and spend between 2 and 3 hours a day online on average ( $3-5$ hours for the youth aged 10-17) with the smartphone being the most frequently used gadget for internet access $(93.4 \%$ of Ukrainians aged 18-29). As for the number of devices owned by Ukrainians, $84.7 \%$ of Ukrainian households have at least one smartphone, $42.7 \%$ of Ukrainian families own a laptop, and $45.6 \%$ a desktop computer (Kabinet Ministriv Ukrainy, 2019).

In our survey, all respondents own at least one device with internet access: a smartphone - 97\%; a tablet $-9.1 \%$; a laptop $-86.4 \%$, a desktop personal computer $-19.7 \%$. Due to the inexpensive mobile data in Ukraine, the great majority of students can have access to the internet practically in any class, even when occasional breakdowns in university's free Wi-Fi may occur. All of the respondents claimed that they use the internet during every or almost every English class, and the most frequent use is determined by the need to translate unfamiliar vocabulary, with online translators being a more popular means than online dictionaries. The internet is also used with the purpose of searching for certain facts presented in their textbooks, news, or grammar rules. In the meantime, $33.3 \%$ claimed that their teachers do not encourage them to use the internet in the classroom. With regards to their use of the internet to do their English homework, students find online dictionaries slightly more useful than online translators, and this small change in attitudes can be explained by the opportunity to perform their tasks at their own pace. Among other reasons to resort to the internet, students named the search for further information on the topic, watching English video lessons online, checking the correct pronunciation of new words, watching films in English, discussing and doing homework with groupmates online, exploring topics discussed in the class further, etc. Students also use online resources in English, such as official IMF, NATO, UN, The World Bank websites, LIBOR, corporate websites of international and foreign companies, international commercial arbitration court, international regulatory acts, research papers, Wikipedia, Google Scholar, BBC, etc., to search for information for the subjects not related to EFL but those they specialise in, such as marketing, management, political economy, economic cybernetics, programming, Web-design, riskology, ethics, history of art, history of religion, etc. Only $7.6 \%$ of the respondents claim that they never use the English language web pages for such purposes, and $53 \%$ do so frequently ( $28.8 \%$ - often, $24.2 \%$ - always or almost always).

\subsection{Ethical issues}

Efforts were made to preserve the anonymity, confidentiality, and fair treatment of the participants' data during this Internet-based study. The potential participants and their instructors were informed via email of the research purpose, significance, and ethics. The concept of informal digital language learning was thoroughly explained to minimise participants' confusion between formal and informal language learning with technology. Students then voluntarily took part in the survey. 


\section{Results and discussion}

The results of the survey attest to regular engagement with the English language involving online technologies. Table 2 shows 17 technologies ranked according to the reported frequency of use (column 1), with two technologies (YouTube and online courses) mentioned twice as we wanted to identify the difference between the use of these tools for learning English and for other purposes. Column 3 shows the percentage of students who reported that they use a particular technology quite frequently and almost always or always, column 6 presents the perceived usefulness of the technology (by which we mean a self-reported belief that a particular technology would enhance one's language performance) and shows the percentage of students who found the technology rather useful or extremely useful, column 9 lists skills and domains and the perceived usefulness of a particular technology for their development or improvement.

Table 2. Technologies used by respondents

\begin{tabular}{|c|c|c|c|c|c|c|c|c|}
\hline \multirow{2}{*}{$\begin{array}{l}\text { Rank } \\
\text { (frequ } \\
\text { ency) }\end{array}$} & \multirow[t]{2}{*}{ Technology } & \multicolumn{3}{|c|}{ Frequency of use } & \multicolumn{3}{|c|}{ Perceived usefulness } & \multirow{2}{*}{$\begin{array}{l}\text { Usefulness for specific skills (\% of } \\
\text { students believe the technology to be } \\
\text { useful) }\end{array}$} \\
\hline & & $\%$ & SD & M & $\%$ & SD & M & \\
\hline 1 & 2 & 3 & 4 & 5 & 6 & 7 & 8 & 9 \\
\hline 1 & $\begin{array}{l}\text { Online } \\
\text { dictionaries }\end{array}$ & $77.3 \%$ & 0.89 & 3.1 & $83.1 \%$ & 0.82 & 4.14 & $\begin{array}{l}\mathbf{V}(78.2 \%), \text { G (36.4\%), R (34.5\%), P (32.7), } \\
\text { W (30.9\%), S (20\%), L (10.9\%), CC (7.3\%) }\end{array}$ \\
\hline 2 & $\begin{array}{l}\text { YouTube (videos } \\
\text { on general topics) }\end{array}$ & $72.7 \%$ & 0.96 & 3.08 & $59.7 \%$ & 1.08 & 3.69 & $\begin{array}{l}\mathbf{P}(62.7 \%), \mathrm{L}(59.3 \%), \mathrm{V}(57.6 \%), \mathrm{S}(47.5 \%) \text {, } \\
\mathrm{CC}(40.7 \%), \mathrm{R}(23.7 \%), \mathrm{G}(22 \%), \mathrm{W}(10.2 \%)\end{array}$ \\
\hline 3 & $\begin{array}{l}\text { Social media } \\
\text { (following } \\
\text { language } \\
\text { influencers on } \\
\text { Facebook, } \\
\text { Instagram, etc.) }\end{array}$ & $68.1 \%$ & 0.97 & 2.94 & $60.9 \%$ & 0.91 & 3.7 & $\begin{array}{l}\text { V }(75.4 \%), \mathrm{R}(72.1 \%), \mathrm{G}(52.5 \%), \mathrm{W} \\
(49.2 \%), \mathrm{CC}(27.9 \%), \mathrm{S}(26.2 \%), \mathrm{P}(24.6 \%), \\
\mathrm{L}(13.1 \%)\end{array}$ \\
\hline 4 & $\begin{array}{l}\text { Text or voice } \\
\text { messages }\end{array}$ & $60.7 \%$ & 1.18 & 2.88 & $64.7 \%$ & 1.09 & 3.65 & $\begin{array}{l}\text { S }(71.4 \%), \mathrm{CC}(63.3 \%), \mathrm{P}(59.2 \%), \mathrm{L} \\
(34.7 \%), \mathrm{G}(34.7 \%), \mathrm{V}(34.7 \%), \mathrm{W}(32.7 \%) \\
\mathrm{R}(22.4 \%)\end{array}$ \\
\hline 5 & $\begin{array}{l}\text { Watching films } \\
\text { and series }\end{array}$ & $51.5 \%$ & 0,88 & 2.71 & $85.9 \%$ & 0,78 & 4,28 & $\begin{array}{l}\text { L }(82.3 \%), \text { V }(74.2 \%), \text { P }(58.1 \%), \text { S }(50 \%), \\
\text { CC }(41.9 \%), \text { R(33.9\%), G (17.7\%), W (8.1\%) }\end{array}$ \\
\hline 6 & $\begin{array}{l}\text { YouTube (videos } \\
\text { related to } \\
\text { language } \\
\text { learning) }\end{array}$ & $45.5 \%$ & 0.87 & 2.5 & $70.4 \%$ & 1.09 & 3.8 & $\begin{array}{l}\mathbf{P}(76.3 \%), \mathrm{V}(67.8 \%), \mathrm{L}(64.4 \%), \mathrm{S}(52.5 \%), \\
\text { G }(45.8 \%), \mathrm{CC}(27.1 \%), \mathrm{R}(18.6 \%), \mathrm{W} \\
(16.9 \%),\end{array}$ \\
\hline 7 & News websites & $44 \%$ & 0.96 & 2.44 & $44.2 \%$ & 0.93 & 3.41 & $\begin{array}{l}\mathbf{R}(85.7 \%), \mathrm{V}(64.3 \%), \mathrm{G}(51.8 \%), \mathrm{W} \\
(35.7 \%), \mathrm{P}(14.3 \%), \mathrm{L}(10.7 \%), \mathrm{S}(8.9 \%), \mathrm{CC} \\
(7.1 \%)\end{array}$ \\
\hline 8 & Online grammars & $40.9 \%$ & 0.84 & 2.29 & $55.8 \%$ & 1.24 & 3.48 & $\begin{array}{l}\text { G }(75 \%), \text { V }(50 \%), \mathrm{R}(41.7 \%), \mathrm{W}(29.2 \%), \mathrm{P} \\
(12.5 \%), \mathrm{CC}(8.3 \%), \mathrm{S}(8.3 \%), \mathrm{L}(6.3 \%)\end{array}$ \\
\hline 9 & $\begin{array}{l}\text { Online courses } \\
\text { related to topics } \\
\text { other than } \\
\text { language learning }\end{array}$ & $40.9 \%$ & 0.99 & 2.21 & $63.8 \%$ & 1.03 & 3.72 & $\begin{array}{l}\text { V }(60.5 \%), \mathrm{R}(42.1 \%), \mathrm{G}(39.5 \%), \mathrm{S} \\
(39.5 \%), \mathrm{L}(31.6 \%), \mathrm{W}(28.9 \%), \mathrm{P}(26.3), \mathrm{CC} \\
(28.9)\end{array}$ \\
\hline 10 & $\begin{array}{l}\text { Reading or } \\
\text { downloading } \\
\text { books online }\end{array}$ & $36.4 \%$ & 1.01 & 2.26 & $66.7 \%$ & 0.97 & 3.88 & $\begin{array}{l}\mathbf{R}(91.1 \%), \mathrm{V}(73.3 \%), \mathrm{G}(51.1 \%), \mathrm{W} \\
(26.7 \%), \mathrm{P}(13.3 \%), \mathrm{CC}(13.3 \%), \mathrm{L}(6.7 \%), \mathrm{S} \\
(4.4 \%)\end{array}$ \\
\hline 11 & $\begin{array}{l}\text { Video chatting } \\
\text { (Skype, } \\
\text { Facebook, etc.) }\end{array}$ & $31.8 \%$ & 1.03 & 2.02 & $72.1 \%$ & 1.09 & 3.88 & $\begin{array}{l}\text { S (94.9\%), P (71.8\%), L (64.1\%), CC } \\
(64.1 \%), \mathrm{V}(38.5 \%), \mathrm{G}(23.1 \%), \mathrm{R}(15.4 \%), \\
\text { W }(7.7 \%)\end{array}$ \\
\hline 12 & $\begin{array}{l}\text { Language } \\
\text { learning sites } \\
\text { (British Council, } \\
\text { BBC Learning } \\
\text { English, etc.) }\end{array}$ & $30.3 \%$ & 0.95 & 2.02 & $75.5 \%$ & 0.88 & 4.04 & $\begin{array}{l}\text { V (75\%), G (65\%), R (60\%), W (45\%), P } \\
(40 \%), \mathrm{L}(40 \%), \mathrm{S}(35 \%), \mathrm{CC}(25 \%)\end{array}$ \\
\hline 13 & Reading blogs & $30.3 \%$ & 0.96 & 2.06 & $53 \%$ & 1.02 & 3.43 & $\begin{array}{l}\text { R }(74.4 \%), \text { V (67.4\%), G (48.8\%), W } \\
(27.9 \%), \mathrm{CC}(23.3 \%), \mathrm{P}(18.6 \%), \mathrm{S}(11.6 \%) \\
\mathrm{L}(11.6 \%)\end{array}$ \\
\hline 14 & Online magazines & $28.8 \%$ & 0.87 & 2.15 & $33.3 \%$ & 0.97 & 3.22 & $\begin{array}{l}\text { R }(84 \%), \mathrm{V}(64 \%), \mathrm{G}(56 \%), \mathrm{W}(44 \%), \mathrm{S} \\
(12 \%), \mathrm{P}(12 \%), \mathrm{L}(8 \%), \mathrm{CC}(8 \%)\end{array}$ \\
\hline 15 & $\begin{array}{l}\text { Online courses } \\
\text { related to } \\
\text { language learning }\end{array}$ & $21.3 \%$ & 0.85 & 1.94 & $\begin{array}{l}76.4 \\
\%\end{array}$ & 0.89 & 4.16 & $\begin{array}{l}\mathrm{V}(85.7 \%), \mathrm{G}(82.6 \%), \mathrm{L}(73.9 \%), \mathrm{R} \\
(65.2 \%), \mathrm{W}(69.6 \%), \mathrm{S}(60.9 \%), \mathrm{CC}(50 \%), \mathrm{P} \\
(50 \%)\end{array}$ \\
\hline 16 & $\begin{array}{l}\text { Listening to } \\
\text { podcasts }\end{array}$ & $21.2 \%$ & 0.97 & 1.8 & $42.6 \%$ & 1.1 & 3.38 & $\begin{array}{l}\text { L }(85.4 \%), \text { V (56.1\%), P (56.1\%), S (36.6\%), } \\
\text { G (22\%), CC (22\%), R (12.2\%), W (2.4\%) }\end{array}$ \\
\hline
\end{tabular}




\begin{tabular}{|l|l|l|l|l|l|l|l|l|}
\hline $\mathbf{1 7}$ & Emailing & $13.6 \%$ & 0.8 & 1.59 & $50 \%$ & 1.05 & 3.33 & $\begin{array}{l}\text { W (94.1\%), G (61.8\%), CC (58.8\%), R } \\
(41.2 \%), \mathrm{V}(41.2 \%), \mathrm{S}(8.8 \%), \mathrm{P}(5.9 \%), \mathrm{L} \\
(2.9 \%),\end{array}$ \\
\hline $\mathbf{1 8}$ & $\begin{array}{l}\text { Listening to the } \\
\text { radio }\end{array}$ & $10.6 \%$ & 0.8 & 1.56 & $20 \%$ & 1.07 & 2.7 & $\begin{array}{l}\text { L }(82.1 \%), \mathrm{P}(48.7 \%), \mathrm{V}(33.3 \%), \mathrm{S}(23.1 \%), \\
\mathrm{CC}(17.9 \%), \mathrm{G}(12.8 \%), \mathrm{W}(5.1 \%), \mathrm{R}(5.1 \%)\end{array}$ \\
\hline $\mathbf{1 9}$ & $\begin{array}{l}\text { Discussion } \\
\text { forums }\end{array}$ & $7.6 \%$ & 0.68 & 1.41 & $44.1 \%$ & 1.28 & 3.41 & $\begin{array}{l}\text { CC (59.3\%), R (37\%), V (37\%), G (33.3\%), } \\
\text { W (29.6\%), S (5.9\%), P (3.7\%), L (3.7\%), }\end{array}$ \\
\hline
\end{tabular}

Notes: $\mathrm{SD}=$ standard deviation, $\mathrm{M}=$ mean, $\mathrm{W}=$ writing, $\mathrm{R}=$ reading, $\mathrm{S}=$ speaking, $\mathrm{L}=$ listening, $\mathrm{P}=$ pronunciation, $\mathrm{G}=$ grammar, $\mathrm{V}=$ vocabulary, $\mathrm{CC}=$ communicative competence

According to the survey, among the top five most frequently used digital tools for informal language learning, which demonstrated the frequency of use above $50 \%$, the students named online dictionaries, YouTube videos on general topics, social media (following language influencers on Facebook, Instagram, etc.), text or voice messages, and watching films and series. Students find these five popular technologies particularly conducive to the development of vocabulary competence, whereas writing skills appear to be the least attended to.

\subsection{Frequency of use}

\subsubsection{Language learning technologies}

Notably, specific language learning tools such as online grammars (40.9\%), language learning websites $(40.9 \%)$, and online language courses $(21.3 \%)$ ranked relatively low in terms of their use frequency, although their perceived usefulness was evaluated rather high. The exception is online dictionaries, which hold the first place among all listed technologies $(77.3 \%)$ and, according to the respondents' views, help develop not only vocabulary but also grammar competence and are significantly more convenient in finding new vocabulary than their paper-based analogues. In the meantime, YouTube videos aimed at language learners are slightly more frequently used than other digital language learning tools $(45.5 \%)$, although they still rank below 50\%. It is worth noting that the respondents emphasise the significant value of such videos presented by native speakers in contrast to the ones produced by other Ukrainians and Russians with their respective translations.

\subsubsection{Audiovisual technologies}

The popularity of audiovisual technologies like YouTube videos, films, and series and their perceived usefulness is supported by the results of previous studies examining students' technology preferences (Trinder, 2017; Conole, 2008; Stevens, 2009; Steel \& Levy, 2013). Students report that these technologies are particularly beneficial for acquiring new vocabulary, enhancing listening skills, pronunciation, and communicative competence, and even though they apparently do not offer any opportunities for language production, the respondents informed that they also help them advance in their speaking skills $(47.5 \%$ for YouTube, $50 \%$ for films and series). These technologies are reported to provide students with authentic language and examples of phrases that they claim to learn effortlessly and have very few opportunities to learn in their formal English classes since they often need to focus on professional ESP vocabulary or more formal vocabulary from their textbooks. Taking into consideration the inherent characteristics of the media and the students' responses, Trinder (2017) deduced the following factors that contribute to its potential efficacy, which correlates with our conclusions for this study: motivation (interesting, engaging, effortless learning, peer group interest); high-context exposure; social and cultural insights; pragmatics; repetitive situations; repeated exposure to lexical chunks, idiomatic language, everyday vocabulary as well as professional lexis; authentic fast speech helped through visual clues, plot, subtitles when necessary; different accents, registers, styles; noticeable (and effortless) language development.

\subsubsection{Communication technologies}

Social networking sites such as Facebook, Instagram, along with texting and voice messaging services (Telegram, messenger, etc.), play an important role in students' personal learning environment, in contrast, emailing, video chatting, and discussion forums are not frequently used even though they are seen as relatively beneficial by those respondents that use them. Unlike in Trinder's (2017) research, who emphasised the communicative importance of social media like Facebook (which gained the top ranking in her research for catering for communicative competence), this network, along with Instagram, is regarded by the respondents of our study as a useful tool for developing vocabulary and grammar competence in the first place, which can be explained by the exponential growth in popularity of language bloggers and influencers who produce "bite-sized" content intended to explain certain lexical or grammar issues of the language. 
Surprisingly, in contrast to Trinder's (2017) findings, in this study, text and voice messaging are among the top five most frequently used technologies. The use of texting and voice messaging is experiencing a growth in uptake since this media is becoming increasingly prevalent among youth, and its particular perceived usefulness for improving speaking, pronunciation, and communicative competence in the English language is related not only to the fact that the respondents have international friends but also that they join special language learning groups on Telegram or other similar communication services.

\subsection{Perceptions of usefulness}

The study shows that the popularity of the technology does not directly correlate with its perceived usefulness. Table 3 compares the frequency of use and the perceived usefulness of the chosen technologies. Although using online dictionaries and watching films and series in English are among the top five activities involving technologies in both lists, such digital tools as online language courses and language learning websites perceived as beneficial by the students do not rank high among the frequently used technologies.

Table 3. The comparison of the frequency of use and perceived usefulness

\begin{tabular}{|c|c|c|}
\hline & $\begin{array}{l}\text { Ranking according to the frequency of use (technology is } \\
\text { used frequently) }\end{array}$ & $\begin{array}{l}\text { Ranking according to the perceived usefulness } \\
\text { (technology is regarded rather useful and extremely } \\
\text { useful) }\end{array}$ \\
\hline 1 & Online dictionaries $77.3 \%$ & Watching films and series $85.9 \%$ \\
\hline 2 & YouTube (videos on general topics) $72.7 \%$ & Online dictionaries $83.1 \%$ \\
\hline 3 & $\begin{array}{l}\text { Social media (following language influencers on Facebook, } \\
\text { Instagram, etc.) } 68.1 \%\end{array}$ & Online courses related to language learning $76.4 \%$ \\
\hline 4 & Text or voice messages $60.7 \%$ & $\begin{array}{l}\text { Language learning sites (British Council, BBC Learning } \\
\text { English, etc.) } 75.5 \%\end{array}$ \\
\hline 5 & Watching films and series $51.5 \%$ & Video chatting (Skype, Facebook, etc.) $72.1 \%$ \\
\hline 6 & YouTube (videos related to language learning) $45.5 \%$ & YouTube (videos related to language learning) $70.4 \%$ \\
\hline 7 & News websites $44 \%$ & Reading or downloading books online $66.7 \%$ \\
\hline 8 & Online grammars $40.9 \%$ & Text or voice messages $64.7 \%$ \\
\hline 9 & $\begin{array}{l}\text { Online courses related to topics other than language } \\
\text { learning } 40.9 \%\end{array}$ & $\begin{array}{l}\text { Online courses related to topics other than language } \\
\text { learning } 63.8 \%\end{array}$ \\
\hline 10 & Reading or downloading books online $36.4 \%$ & $\begin{array}{l}\text { Social media (following language influencers on } \\
\text { Facebook, Instagram, etc.) } 60.9 \%\end{array}$ \\
\hline 11 & Video chatting (Skype, Facebook, etc.) $31.8 \%$ & YouTube (videos on general topics) $59.7 \%$ \\
\hline 12 & $\begin{array}{l}\text { Language learning sites (British Council, BBC Learning } \\
\text { English, etc.) } 30.3 \%\end{array}$ & Online grammars $55.8 \%$ \\
\hline 13 & Reading blogs $30.3 \%$ & Reading blogs $53 \%$ \\
\hline 14 & Online magazines $28.8 \%$ & Emailing 50\% \\
\hline 15 & Online courses related to language learning21.3\% & News websites $44.2 \%$ \\
\hline 16 & Listening to podcasts $21.2 \%$ & Listening to podcasts $42.6 \%$ \\
\hline 17 & Emailing13.6\% & Discussion forums $44.1 \%$ \\
\hline 18 & Listening to the radio $10.6 \%$ & Online magazines $33.3 \%$ \\
\hline 19 & Discussion forums $7.6 \%$ & Listening to the radio $20 \%$ \\
\hline
\end{tabular}

According to the students' views, vocabulary competence is best developed by the use of online dictionaries, social media, language and non-language online courses, special language websites, watching films and series as well as YouTube videos. The respondents see social media, online dictionaries, online courses, and, naturally, online grammars as the technologies that can help them develop their grammar competence, and text/voice messages, films, series, YouTube videos, and podcasts as such that can help improve their pronunciation. Writing appears to be not a very popular skill and is presumably best developed by the use of emailing and social media. Social media, along with online courses, blogs, and, obviously, books, help develop reading skills, according to the respondents' opinions, while watching films, series, online language courses, or YouTube videos helps with improvements in the listening domain, which comes as no surprise. Text or voice messages help with developing speaking skills and communication competence. The respondents do not specify how YouTube videos facilitate the development of speaking competence, although many of them voted for this technology as being useful for enhancing this skill in particular. However, we may assume that it enables the students to learn practical language patterns, which they may use later while speaking.

Having analysed the students' engagement with the most frequently used technologies, we can conclude that an aspect of the English language which is most frequently developed through informal learning is 
vocabulary. However, students lack practice in writing and communicative competence.

\subsection{Reasons behind choosing a particular digital tool}

In the questionnaire, a number of open-ended questions encouraged students to formulate their own ideas on why they preferred using a certain online resource and why other online resources were not favoured. The generated qualitative data is intended to provide insights into the students' reasons behind the choice of a particular digital tool. Respondents' replies demonstrated considerable awareness of the outcomes and benefits of informal engagement with the English language media for the improvement of their language level.

Such activities as watching YouTube videos, following English social media accounts by interests or aimed at language learners, and watching films or series received high ranking, which supports the hypothesis that for informal language learning, students prefer media that offer an entertaining component. Indeed, the respondents commented that they found films and video resources "interesting and useful at the same time", they help "increase vocabulary" and "improve pronunciation", some of them admitted that they normally "reluctantly learn English" but with films, they do this "effortlessly" and "willingly learn new words, learn to catch them by listening". They often watch videos on YouTube because they find it "convenient and (they) can do it in the meantime while doing something else". Several students specifically referred to the TedTalks channel on YouTube as they find the videos engaging and comprehensible as well as particularly conducive for improving vocabulary and communicative competence. One of the students commented on watching films and series by saying that it is the tool they use most frequently "first of all, because (they) personally find it interesting, and since (they) are interested, (they) do not regard English as studying. As a result, English becomes the tool for understanding important information; therefore, (they) will put in a lot of effort in improving (their) knowledge and comprehension. Besides, the native speakers' pronunciation and sentence structure is "practical material", which serves as a model for vocabulary and grammar use". Additionally, watching YouTube videos helps students maintain the level of English they have already acquired, as one of them succinctly noted: "YouTube helps me not to forget what I already know".

The respondents believe that following social media accounts has a certain impact on their English language: "English Facebook pages provide with the opportunity to engage with English every day", "Instagram (English blogs) never gets (me) bored and (I) can watch interesting videos at any moment", "Instagram pages in English on history and geography help increase vocabulary", "Twitter contains a lot of jokes, English culture, very specific vocabulary". Students also claim to use Messenger and Telegram channels to practice their speaking skills and "enrich vocabulary" since the use of voice messaging is gaining greater popularity. Telegram is also considered to be an environment that offers different "channels by interests that often get updated". Professional online books and websites are regarded to be "reliable sources of information that help develop not only knowledge in the professional sphere but also language skills". Some respondents admit that they improve their vocabulary and language skills while coding and using code documentation, which leads to better language ability in the future.

Students do not find emailing useful as they consider it obsolete since there are faster and more efficient means of communication such as social networking sites, voice messages, or video calls. In the meantime, some of them find video calls in English intimidating and need "to pluck up their courage to finally try it". Online courses are listed among less popular tools because that they require "time and a great deal of commitment". One of the respondents commented on their unwillingness to use radio or podcasts by admitting to having poor listening skills and therefore suffering to concentrate on audio solely. Among the challenges that students face while using online technologies, they named the fact of being often distracted by other sites and applications (66.7\%), poor internet connection (21.2\%), the lack of necessary skills $(10.6 \%)$, the lack of time or motivation $(3 \%)$, advertisement $(1.5 \%)$, the fact that some good resources are not free $(1.5 \%)$.

\subsection{Implications for research and practice}

The study has implications for foreign language learners, teachers, and researchers of second language acquisition for incorporating online digital tools for foreign language acquisition beyond the classroom. In particular, for foreign language learners who have the disadvantage of living in a non-English speaking environment, such as Ukrainian students, informal digital language activities can prove to be one of the beneficial and effective ways to increase their limited opportunities to learn and use English and therefore improve their foreign language outcomes by taking advantage of already existing digital technologies (e.g., watching films, using social media, etc.). In the meantime, it is important to keep in mind that not every out-of-class engagement with technology has an equal impact. In this regard, foreign language teachers play 
a significant role in influencing students' use of technology outside the classroom. Informed teachers' support could affect and enhance the quality of students' engagement with digital technology for informal language learning and facilitate better results. Taking into consideration students' individual learning needs and styles while creating an instructional design would also increase students' motivation to learn a foreign language. Therefore, language teacher professional education and development need not only to focus on effective practices in a formal institutional context but also to include a component on how to integrate informal learning contexts to help students construct a fully integrated learning experience.

\subsection{Recommendations for educators}

Being aware of how students engage with technology outside the classroom may facilitate educators in increasing learners' engagement with the foreign language, provide additional practice, and also produce an emotional response, which increases retention of information. Informal learning with online tools may result in higher-order thinking skills and more confidence for students directing their own learning. All this may particularly benefit ESP students since they predominantly focus on discipline-specific terms minimizing the time for practising general English vocabulary. Besides, considering the challenges associated with the amount of time allocated to every student in a formal group setting, informal use of English online tools may help provide this time in a more engaging way.

\subsection{Limitations}

This research was mainly based on data collected through learners' self-reports. However, the usefulness of the technologies for the language acquisition and development of particular skills could have been measured better through experimental research. The sample of this study comes from one university, which also limits the external validity of the research.

Given the fact that the participants were from a similar socio-cultural background (Ukrainian university students), these results may not be representative of the other foreign language learners. Participants from different universities and other countries would need to be recruited to substantiate the present results.

\subsection{Suggestions for further research}

This study is a small attempt at understanding the quality of informal language learning experiences. More research is needed to explore further different characteristics of the quality out-of-class learning experiences in different learning situations and different contexts in Ukraine and worldwide. Experimental research with pre- and post- measures is needed to investigate the causal relationships between the variables. The research into the positive correlation between the diversity of out-of-class learning experiences and learning outcomes may well prove to be meaningful. Further studies may consider looking into a particular general skill (e.g., listening, reading) or even splitting up a general skill based on the specific purpose of the learning activity (e.g., listening for gist, reading for details, etc.)

\section{Conclusion}

In this article, we have attempted to explore the informal learning environment of non-linguist students and their attitudes towards various online applications and tools that allow them to practice and use the English language. The use of some internet resources has clearly become normalised, such as students turning to the internet to search for further information, both for their English classes and those that are their major-specific or looking up the meaning of new words and phrases in online dictionaries or translators. Students' preferences are distinctly inclined towards the use of technologies that offer at least some entertaining components such as films, YouTube, social media (Instagram, Facebook), and they have to be convinced of the value of language-specific technologies, such as online grammars, language learning websites, or courses.

This study shows that students are rather active in their English language use and demonstrate a positive attitude while engaging with different online tools. Moreover, the use of such informal learning technologies may well help them transition from language learners regarding foreign language as an end in itself into language users able to apply their knowledge of the language in actual performance. Addressing this new reality by the teacher may enhance students' learning experiences, add to motivating factors and create a more authentic and student-centred environment. It may prove to be beneficial to relate formal ways of learning to informal ones by asking students to share some digital resources in class. This discussion may address another issue that is of digital literacy, which students face while being inundated with all the information online, as well as issues of plagiarism and online security. 


\section{References:}

Akkara, S., Anumula V. S. S., \& Mallampalli, M. S. (2020). Impact of WhatsApp Interaction on Improving L2 Speaking Skills. International Journal of Emerging Technologies in Learning (iJET), 15(03), $250-259$. https://doi.org/10.3991/ijet.v15i03.11534

Baird, D. E., \& Fisher, M. (2005). Neomillennial User experience design strategies: Utilizing social networking media to support "always on" learning styles. Journal of Educational Technology Systems, 34(1), 5-32. https://doi.org/10.2190/6WMW47L0-M81Q-12G1

Benson P. (2011). Language Learning and Teaching Beyond the Classroom: An Introduction to the Field. In: Benson P., Reinders H. (Eds), Beyond the Language Classroom (pp. 7-16). London: Palgrave Macmillan. https://doi.org/10.1057/9780230306790_2

Benson, P., \& Reinders, H. (Eds). (2011). Beyond the language classroom. New York: Palgrave Macmillan.

Burston, J. (2014). MALL: the pedagogical challenges. Computer Assisted Language Learning, 27, $344-357$. https://doi.org/10.1080/09588221.2014.914539

Burston, J. (2015). Twenty years of MALL project implementation: a meta-analysis of learning outcomes. ReCALL, 27, 4-20. https://doi.org/10.1017/S0958344014000159

Che, CWIRB, Ibrahim, W. (2018). Social media tools for informal language learning: A Comprehensive Theoretical Framework. Asian Social Science, 14 (4), 46-50. https://doi.org/10.5539/ass.v14n4p46

Conlon, T.J. (2004) A review of informal learning literature, theory, and implications for practice in developing global professional competence. Journal of European Industrial Training, 28, 283-295. http://dx.doi.org/10.1108/03090590410527663

Conole, G. (2008). Listening to the learner voice: the ever-changing landscape of technology use for language students. ReCALL, 20(2), 124-40. https://doi.org/10.1017/S0958344008000220

Dizon, G. (2021). Subscription video streaming for informal foreign language learning: Japanese EFL students' practices and perceptions. TESOL Journal, e 566. https://doi.org/10.1002/tesj.566

Eraut, M. (2000). Non-formal learning and tacit knowledge in professional work. British Journal of Educational Psychology, 70(1), 113-136. https://doi.org/10.1348/000709900158001

Godwin-Jones, R. (2018). Chasing the butterfly effect: Informal language learning online as a complex system. Language Learning \& Technology, 22(2), 8-27. https://doi.org/10125/44643

Godwin-Jones, R. (2019). Riding the digital wilds: Learner autonomy and informal language learning. Language Learning \& Technology, 23(1), 8-25. https://doi.org/10125/44667

Gonulal, T. (2019). The use of instagram as a mobile-assisted language learning tool. Contemporary Educational Technology, 10(3), 309-323. https://doi.org/10.30935/cet.590108

Hall, R. (2009). Towards a fusion of formal and informal learning environments: the impact of the read/write web. Electronic Journal of e-Learning, 7(1), 29-40. Retrieved from https://files.eric.ed.gov/fulltext/EJ867100.pdf

Hockly, N. (2015). Developments in online language learning, ELT Journal, 69(3), 308-313, https://doi.org/10.1093/elt/ccv020

Holec, H. (1981). Autonomy and foreign language learning. Oxford, UK: Pergamon Press

Huzairin,H., Putrawan, G., E., \& Riadi, B. (2020). Technology and language learning: English as a Foreign Language learners' use of smartphones for online informal learning in Indonesia. Texto Livre Linguagem e Tecnologia, 13(3), 103-120. https://doi.org/10.35699/1983-3652.2020.24657

Ismail, I. S., \& Shafie, N. H. bt. (2019). English informal language learning through social networking sites among Malasian university students. Asian Journal of University Education, 15(3), 211-225. https://eric.ed.gov/?id=EJ1238630

Jensen, S. H. (2017). Gaming as an English language learning resource among young children in Denmark. CALICO Journal, 34, 119. https://doi.org/10.1558/cj.29519

Jurkovič, V. (2018). Online informal learning of English through smartphones in Slovenia. System, 80,27-37. https://doi.org/10.1016/j.system.2018.10.007

Kabinet Ministriv Ukrainy. (2019, December 24). Prezentatsiia pershoho v Ukraini doslidzhennia z tsyfrovoi hramotnosti naselennia [Video file]. Retrieved from https://www.youtube.com/watch?v=t3ghLyjzqLM\&feature=youtu.be

Lai, C., Zhu, W., \& Gong, G. (2015). Understanding the quality of out-of-class English learning. TESOL Quarterly, 49(2), 278-308. https://doi.org/10.1002/tesq.171

Lee, J. S. (2020). The role of informal digital learning of English and a high-stakes English test on perceptions of English as an international language. Australasian Journal of Educational Technology, 36(2), 155-168. https://doi.org/10.14742/ajet.5319

Lee, J. S., \& Drajati, N. A. (2019). Affective variables and informal digital learning of English: Keys to willingness to communicate in a second language. Australasian Journal of Educational Technology, 35(5), 168-182. https://doi.org/10.14742/ajet.5177

Lee, J. S., \& Dressman, M. (2017). When IDLE hands make an English workshop: Informal digital learning of English and language proficiency. TESOL Quarterly, 52(2), 435-445. https://doi.org/10.1002/tesq.422

Li, T., Zou, D., Weng, X., Wang, M., Xie, H., \& Wang, F. L. (2020) Acceptance and implications of smartphones for informal language learning in foreign study tours. International Journal of Mobile Learning and Organisation, 14 (4), $456-477$. https://doi.org/10.1504/IJMLO.2020.110783

Messmann, G., Segers, \& M., Dochy, F. (Eds.). (2018). Informal Learning at Work: Triggers, Antecedents, and Consequences. Routledge

Mitra, S., Tooley, J., Inamdar, P., \& Dixon, P. (2003). Improving English pronunciation: an automated instructional approach. Information Technologies and International Development, 1(1), 75-84. https://doi.org/10.1162/154475203771799720

Oblinger D.G., Oblinger J.L. (2005). Educating the net generation. Washington, DC: Educause.

Peng, H., Jager, S., \& Lowie, W. (2021) A person-centred approach to L2 learners' informal mobile language learning. Computer Assisted Language Learning. https://doi.org/10.1080/09588221.2020.1868532

Peters, M., Weinberg, \& A., Sarma, N. (2009). To Like or Not to Like! Student Perceptions of Technological Activities for Learning French as a Second Language at Five Canadian Universities. Canadian Modern Language Review, 65(5), 869-896. http://dx.doi.org/10.3138/cmlr.65.5.869

Pooley, A. W., Midgley, W., \& Farley, H. (2019). Informal language learning through mobile instant messaging among university students in Korea. International Journal of Mobile and Blended Learning, 11(2), 33-49. https://doi.org/10.4018/IJMBL.2019040103 
Prensky, M. (2001). Digital Natives, Digital Immigrants Part 1. On the Horizon, 9(5), 1-6. https://doi.org/10.1108/10748120110424816

Purnamasari, A. (2019). Pre-Service EFL teachers' perception of using Facebook group for learning. Journal of English Teaching, 5(2), 104-114. http://dx.doi.org/10.33541/jet.v5i2.1064

Putrawan, G., E., \& Riadi, B. (2020). English as a Foreign Language (EFL) learners' predominant language use for online informal learning activities through smartphones in Indonesian context. Universal Journal of Educational Research, 8(2), 695 - 699. https://doi.org/10.13189/ujer.2020.080243.

Rogers, A. (2008). Informal learning and literacy. In B. Street and N. H. Hornberger (Eds), Encyclopedia of Language and Education (2nd ed., vol. 2, pp. 1-12). https://doi.org/10.1007/978-0-387-30424-3_41

Şad, S. N., Özer, N., Yakar, Ü., \& Öztürk, F. (2020) Mobile or hostile? Using smartphones in learning English as a foreign language, Computer Assisted Language Learning. https://doi.org/10.1080/09588221.2020.1770292

Schmidt, R. (1994). Deconstructing consciousness in search of useful definitions for applied linguistics. AILA Review, 11, 11-26.

Scholz, K. W., \& Schulze, M. (2017). Digital-gaming trajectories and second language development. Language Learning \& Technology, 2l(1), 99-119. https://dx.doi.org/10125/44597

Sockett, G. (2013). Understanding the online informal learning of English as a complex dynamic system: An emic approach. ReCALL, 25(1), 48-62. https://doi.org/10.1017/S095834401200033X

Soltovets, E., Chigisheva, O., \& Dubover, D. (2019) Curso electrónico de idioma extranjero como medio de formación informal del desarrollo de alfabetización digital. Revista Dilemas Contemporáneos: Educación, Política y Valores, VI(3:50), 1-15. https://www.dilemascontemporaneoseducacionpoliticayvalores.com/index.php/dilemas

State Statistics Service of Ukraine. (2019). Communication subscribers as of January 1, 2019. Retrieved from http://www.ukrstat.gov.ua/operativ/operativ2019/zv/az/az_e/az0119_e.htm

Steel, C., \& Levy, M. (2013). Language students and their technologies: charting the evolution 2006- 2011. ReCALL, 25(3), 306-20. https://doi.org/10.1017/S0958344013000128

Stevens, A. (ed.). (2010, February 17). Study on the Impact of Information and Communications Technology (ICT) and New Media on Language Learning: Final Report. Retrieved from https://ec.europa.eu/digital-single-market/en/news/report-impactinformation-and-communication-technology-ict-and-new-media-language-learning

Sundqvist, P., \& Sylven, L. K. (2014). Language-related computer use: focus on young L2 English learners in Sweden. ReCALL, 26(1), 3-20. https://doi.org/10.1017/S0958344013000232

Sundqvist, P., \& Wikstrom, P. (2015). Out-of-school digital gameplay and in-school L2 English vocabulary and outcomes. System, 51, 65-76. https://doi.org/10.1016/j.system.2015.04.001

Sung, Y.-T., Chang, K.-E., \& Yang, J.-M. (2015). How effective are mobile devices for language learning? A meta-analysis. Educational Research Review, 16, 68-84. https://doi.org/10.1016/j.edurev.2015.09.001

Tissot, P. (2004). Terminology of vocational training policy: A multilingual glossary of key terms. Luxembourg: Office for Official Publications of the European Communities.

Toffoli, D., \& G. Sockett. (2015). University teachers' perceptions of Online Informal Learning of English (OILE). ComputerAssisted Language Learning, 28(1), 7-21. https://doi.org/10.1080/09588221.2013.776970

Trinder, R. (2017). Informal and deliberate learning with new technologies. ELT Journal, 71(4), 401412. https://doi.org/10.1093/elt/ccw117

Vazquez-Calvo, B. (2020). Guerrilla fan translation, language learning, and metalinguistic discussion in a Catalan-speaking community of gamers. ReCALL, 1-18. https://doi.org/10.1017/S095834402000021X

Watkins, K. E., \& Marsick, V. J. (1992). Towards a theory of informal and incidental learning in organizations. International Journal of Lifelong Education, 11(4), 287-300. https://doi.org/ 10.1080/0260137920110403 